\title{
Integrated Course for Improve Student Competencies on School Physics Laboratory Management
}

\author{
Raihanati $^{1, a)}$, Upik Rahma Fitri $^{2, b)}$, M. Fajrin ${ }^{\text {() }}$ \\ ${ }^{1}$ Program Studi Pendidikan Fisika FMIPA UNJ \\ ${ }^{2}$ Laboratorium Pengembangan Media Pembelajaran Fisika, FMIPA Universitas Negeri Jakarta \\ Email: a) raihanati57@gmail.com, ${ }^{\text {b) }}$ upik.rahma.fitri@gmail.com, ${ }^{\mathrm{c})}$ mfajrin@gmail.com
}

\begin{abstract}
School Physics Laboratory Management is one of the subjects in Physics Education Study Program on FMIPA UNJ which aims to build the competence of school laboratory management for physics education students. It have been developed integrated teaching materials consisting of syllabus, One Semester (RPS) Plan, hand out, Student Activity Sheet, and Student Performance Appraisal Sheet for Laboratory Administration Competence. The development model referred to is ADDIE. Has been validation with college Lecturer Physics Education Studies Program FMIPA UNJ, with the focus of validation of syllabus and OneSemester Lecture Plan (RPS). The recommendation of peers is the use of the tools developed in the lecture process. One Semester (RPS), hand out, Student Activity Sheet, and Student Performance Appraisal Sheet have been tested against the students. Student responses to lectures were collected using a questionnaire consisting of four pieces of grain. Students appreciate 84,59 , meaning very good. The effectiveness of the use of lecture tools in building student competence is very high, which obtained an average score of 91.65 very good category. The results of the experiments show that the lecture tools developed are suitable for use as teaching materials.
\end{abstract}

Keywords: integrated lecturing tools, student competence, laboratory management.

\begin{abstract}
Abstrak
Manajemen Laboratorium Fisika Sekolah merupakan salah satu mata kuliah pada Program Studi Pendidikan Fisika FMIPA UNJ yang bertujuan membangun kompetensi pengelolaan laboratorium sekolah bagi mahasiswa pendidikan fisika. Telah dikembangkan bahan ajar terpadu yang terdiri dari silabus, Rencana Perkuliahan Satu Semester (RPS), hand out,Lembar kegiatan Mahasiswa, dan Lembar Penilaian Kinerja Mahasiswa untuk kompetensi Administrasi Laboratorium. Model pengembangan yang diacu adalah ADDIE. Telah dilakukan validasi sejawat dengan Dosen Program Studi Pendidikan Fisika FMIPA UNJ, dengan focus validasi silabus dan Rencana Perkuliahan Satu Semester (RPS). Rekomendaso teman sejawat adalah penggunaan perangkat yang dikembangkan dalam proses perkuliahan. Rencana Perkuliahan Satu Semester (RPS), hand out,Lembar kegiatan Mahasiswa, dan Lembar Penilaian Kinerja Mahasiswa telah diujicoba terhadap mahasiswa. Respon mahasiswa terhadap perangkat perkuliahan dikumpulkan menggunakan angket yang terdiri dari empatbelah butir. Mahasiswa memberikan apresiasi 84,59, artinya sangat baik. Efektivitas penggunaan perangkat perkuliahan dalam membangun kompetensi mahasiswa sangat tinggi, dimana diperoleh skor rerata sebesar 91,65 kategori sangat baik. Hasil ujicoba menunjukan bahwa perangkat perkuliahan yang dikembangkan layak digunakan sebagai bahan ajar.
\end{abstract}

Kata-kata Kunci: perangkat perkuliahan terpadu, kompetensi mahasiswa, pengelolaan laboratorium. 


\section{PENDAHULUAN}

Calon guru fisika harus menguasai kompetensi pedagogik sebagai bekal mendidik seorang guru. Menurut Usman (dalam Andaru Werdayanti, 2008: 79) kompetensi guru (pedagogik) merupakan kemampuan seorang guru dalam melaksanakan kewajiban-kewajiban secara layak. Ada sepuluh kompetensi guru menurut P3G, yakni: (1) menguasai bahan, (2) mengelola program belajar mengajar, (3) mengelola kelas, (4) menggunakan media/sumber belajar, (5) menguasai landasan pendidikan, (6) mengelola interaksi belajar mengajar, (7) menilai prestasi belajar, (8) mengenal fungsi dan layanan bimbingan penyuluhan, (9) mengenal dan menyelenggarakan administrasi sekolah, (10) memahami dan menaksirkan hasil penelitian guna keperluan pengajaran (Andaru Werdayanti, 2008: 79). Pada point (4) dan (6) dalam kompetensi guru yang dijelaskan terdapat bahwa salah satu kompetensi yang harus dimiliki guru yaitu melaksanakan pembelajaran berbasis keterampilan proses sains.

Menurut Subiyanto dalam Taufi qurrohman (2000), salah satu tujuan pendidikan sains adalah mengembangkan metode pembelajaran melalui metode praktikum. Metode praktikum juga dapat dilaksanakan untuk mengembangkan keterampilan proses sains (Sri Wardani, 2008: 317).

Ketrampilan proses sains pada pembelajaran fisika berlangsung di laboratorium. Dalam kegiatan laboratorium siswa lebih aktif dalam menemukan pengetahuan karena dapat bertukar informasi dengan teman kelompok dan menggunakan kemampuan yang telah dimiliki. U. Nugroho dalam Yaqin (2005) menyatakan, kegiatan di laboratorium memegang peranan penting dalam pendidikan IPA, karena dapat memberikan metode ilmiah kepada siswa (U. Nugroho, 2009: 108). Sehingga dalam pembelajran fisika di laboratorium, siswa akan mendapatkan pengalaman secara langsung dalam menghadapi suatu permasalahan, hal ini merupakan ciri dari keterampilan proses sains.

Dalam rangka mengoptimalkan pemanfaatan sarana laboratorium dalam pembelajaran fisika, seorang guru fisika harus memiliki pengetahuan dan ketrampilan bekerja di laboratorium. Calon guru fisika harus diberi pengalaman belajar yang dapat meningkatkan kompetensi mereka memberdayakan laboratorium. Proses sains sebaiknya diajarkan melalui praktikum, tetapi hal ini pun jarang dilakukan oleh para guru karena beberapa alasan, diantaranya tidak ada waktu khusus untuk praktikum, tidak memadai alat dan bahan praktikum, dan sebagian lagi tidak menguasai cara kerja di laboratorium. Padahal praktikum memegang peran penting di dalam pembelajaran sains (Oom Romlah, 2009: 1). Pembelajaran fisika termasuk dalam sains sehingga pembelajaran fisika sebaiknya diajarkan melalui praktikum. Dari penjelasan di atas, keterampilan guru dalam menggunakan laboratorium sangat penting agar proses pembelajaran sains dapat terpenuhi.

Dalam melaksanakan tugas sebagai pendidik, ada kalanya seorang guru diberi tugas tambahan sebagai Ketua/ coordinator laboratorium Fisika sekolah. Untuk menjalankan tugas tersebut dibutuhkan kompetensi lebih dari sekadar memanfaatkan laboratorium dlam pembelajaran. Kompetensi tambahan yang dibutuhkan adalah Manajemen atau pengelolaan laboratorium.

Sebagai bekal bagi mahasiswa Pendidikan fisika menjalankan tugas tambahan berupa Ketua laboratorium Fisika, Program Studi Pendidikan Fisika memfasilitasi dengan mata kuliah Manajemen Laboratorium. Cakupan manajemen laboratorium sains (termasuk fisika) yaitu perencanaan tataletak laboratorium dan bentuk desain laboratorium dan pelaksaan laboratorium yang meliputi: 1) organisasi dan manajemen laboratorium, 2) keamanan dan keselamatan kerja laboratorium, serta 3) penyimpanan, pemeliharaan, dan perbaikan alat-alat laboratorium (Ahmad Abu Hamid, 2011: 5).

Belum ditemukan sumber dan bahan ajar yang memadai untuk memupuk kompetensi mahasiswa dalam manajemen laboratorium fisika sekolah. Guna memaksimalkan pemupukan kompetensi mahasiswa terkait manajemen laboratorium tersebut, perlu disusun perangkat perkuliahan yang terpadu dan terintegrasi. Untuk menghasilkan perangkat pembelajaran yang berkualitas baik, menurut pendapat Akker (1999:126) perangkat pembelajaran tersebut mesti memiliki kriteria kevalidan (validity), kepraktisan (practically), dan keefektifan (effectiveness). Untuk memenuhi ketiga kriteria tersebut, pengembangan perangkat pembelajaran pada penelitian ini melalui tiga tahapan yaitu self evaluation, prototypin (validasi, evaluasi dan revisi) dan field test (Ali Syahbana, 2012: 21).

Diharapkan perangkat yang dikembangkan dapat memberikan pengalaman belajar yang menerapkan ketrampilan proses sains, sekaligus memupuk kompetensi mahasiswa Pendidikan dalam manajemen laboratorium. 


\section{METODE PENELITIAN}

Penelitian ini bertujuan mengembangkan perangkat perkuliahan terpadu yang layak sebagai bahan ajar untuk mata kuliah Manajemen Laboratorium Fisika Sekolah. Penelitian dilaksanakan pada Program Studi Pendidikan Fisika FMIPA Universitas Negeri Jakarta, pada tahun 2016, menerapkan model penelitian pengembangan yang mengacu pada model ADDIE, dengan tahapan studi pendahuluan (analize), penulisan desain (design), pengembangan perangkat perkuliahan (developed), ujicoba (implementation), dan evaluasi (evaluate). Kelayakan perangkat perkuliahan terpadu hasil pengembangan dilihat dari hasil validasi teman sejawat dan ujicoba terhadap mahasiswa. Respon mahasiswa terhadap perangkat perkuliahan hasil pengembangan dijaring menggunakan instrument berupa quesioner terdiri dari empat belas butir. Sedangkan efektivitas penggunaan perangkat perkuliahan dilihat dari hasil penilaian kinerja mahasiswa pada mata kuliah Manajemen laboratorium Fisika Sekolah. ujicoba melibatkan mahasiswa yang terdaftar sebagai peserta mata kuliah tersebut pada semester ganjil 2016/2017, yang berjumlah 13 orang.

\section{HASIL DAN PEMBAHASAN}

Hasil penelitian ini berupa perangkat perkuliahan untuk mata kuliah Manajemen Laboratorium pada Program Studi Pendidikan Fisika. Produk yang dihasilkan disajikan pada TABEL 1.

TABEL 1. Produk Penelitian.

\begin{tabular}{lllll}
\hline \multirow{2}{*}{ No } & Jenis Produk & $\begin{array}{l}\text { Fungsi Lab. Fisika } \\
\text { Sekolah }\end{array}$ & $\begin{array}{l}\text { Perangkat } \\
\text { Administrasi } \\
\text { Fisika Sekolah }\end{array}$ & $\begin{array}{l}\text { Lab. } \\
\text { Standar Lab. Fisika } \\
\text { Sekolah }\end{array}$ \\
\hline 1 & Silabus mata kuliah & $\begin{array}{l}\text { Semua materi ajar } \\
\text { Fisika }\end{array}$ & pada mata kuliah Pengembangan Bahan Ajar \\
\hline 2 & Hand Out & $\sqrt{ }$ & $\sqrt{ }$ & $\sqrt{ }$ \\
\hline 3 & $\begin{array}{l}\text { Lembar Kegiatan } \\
\text { Mahasiswa }\end{array}$ & $\sqrt{ }$ & $\sqrt{ }$ & $\sqrt{ }$ \\
\hline 4 & $\begin{array}{l}\text { Lembar Penilaian } \\
\text { Kinerja Mahasiswa }\end{array}$ & $\sqrt{ }$ & $\sqrt{ }$ & \\
\hline
\end{tabular}

Validasi Sejawat

TABEL 2. Tabel Data Validasi Sejawat.

\begin{tabular}{|c|c|c|c|}
\hline No & Topik Bahasan & Masukan Sejawat & Produk \\
\hline 1 & $\begin{array}{l}\text { Silabus Mata Kuliah } \\
\text { Manajemen } \\
\text { Laboratorium. }\end{array}$ & $\begin{array}{l}\text { sebaiknya dibuat berbasis penyelsesian } \\
\text { masalah dan melatih ketrampilan } \\
\text { proses sains. Memberikan latihan } \\
\text { terkait dengan kompetensis } \\
\text { pengelolaan laboratorium fisika } \\
\text { sekolah, seperti membuat perangkat } \\
\text { Adm lab, mengiventarisasi, dan tugas } \\
\text { lainnya yang relevan. }\end{array}$ & $\begin{array}{l}\text { Silabus mata kuliah } \\
\text { Manajemen Laboratorium. }\end{array}$ \\
\hline 2 & $\begin{array}{l}\text { Perangkat perkuliahan } \\
\text { Manajemen } \\
\text { Laboratorium. }\end{array}$ & $\begin{array}{l}\text { Sebaiknya disusun berbasis } \\
\text { ketrampilan proses sains dan } \\
\text { memberikan pengalaman yang dapat } \\
\text { melatih kemampuan mahasiswa secara } \\
\text { utuh dan terintegrasi terkait, serta } \\
\text { saling bersinergi dalam memupuk } \\
\text { kompetensi mahasiswa mengelola } \\
\text { laboratorium fisika sekolah. }\end{array}$ & $\begin{array}{l}\text { Hand out, Lembar } \\
\text { Kegiatan Mahasiswa, dan } \\
\text { Lembar Penilaian Kinerja } \\
\text { Mahasiswa berbasis } \\
\text { ketrampilan proses sains } \\
\text { untuk materi membuat } \\
\text { fungsi, perangkat } \\
\text { administrasi, dan standar } \\
\text { operasi laboratorium fisika } \\
\text { sekolah. }\end{array}$ \\
\hline
\end{tabular}


Validasi sejawat dilakukan oleh teman sejawat tim dosen pengampu mata kuliah kelompok Dasar Kependidikan. Validasi dilakukan dengan cara melakukan beberapa kali diskusi intensif baik pada saat merencanakan, melaksanakan, maupun ujicoba implementasi perangkat mata kuliah hasil pengembangan. Di dalam diskusi digali berbagai informasi tentang permasalahan dan kebutuhan mahasiswa akan bahan ajar manajemen laboratorium, tuntutan kompetensi mahasiswa sebagai calon guru fisika di abad 21, khususnya terkait pengelolaan laboraorium fisika sekolah. Hasil validasi sejawat, secara singkat disajikan pada TABEL 2.

\section{Ujicoba Produk}

Telah dilakukan ujicoba terhadap produk penelitian. Perangkat perkulihan yang terdiri dari hand out, Lembar Kerja Mahasiswa, dan Lembar Penilaian Kinerja Mahasiswa, untuk materi fungsi laboratorium, perangkat administrasi laboratorium, dan standar operasi laboratorium. Ujicoba dilakukan terhadap tigabelas orang mahasiswa Pendidikan Fisika FMIPA UNJ yang mengikuti mata kuliah Manajemen Laboratorium Fisika Sekolah pada semester 105.

Data hasil ujicoba berupa (1) respon mahasiswa terhadap perangkat perkuliahan yang dikembangkan, dikumpulkan menggunakan angket, mencakup tiga aspek, yaitu materi/ isi, penyajian, dan bahasa, yang terdiri dari empatbelas butir, dengan empat kategori penilaian 1, 2, 4, dan 5; (2) kompetensi mahasiswa terkait pengelolaan laboratorium yang jumlah butirnya sesuai dengan indicator untuk masing-masing materi perkuliahan dan jumlah point aktivitas belajar dan target belajar, pada masing-masing materi kuliah.

Data respon atau penilaian mahasiswa terhadap produk bahan ajar mata Kuliah Manajemen Laboratorium Fisika Sekolah, berkisar antara 78,57 sampai 87,14, dengan rerata 84,59. Sebaran penilaian respon terhadap masing-masing butir disajikan pada GAMBAR 1.

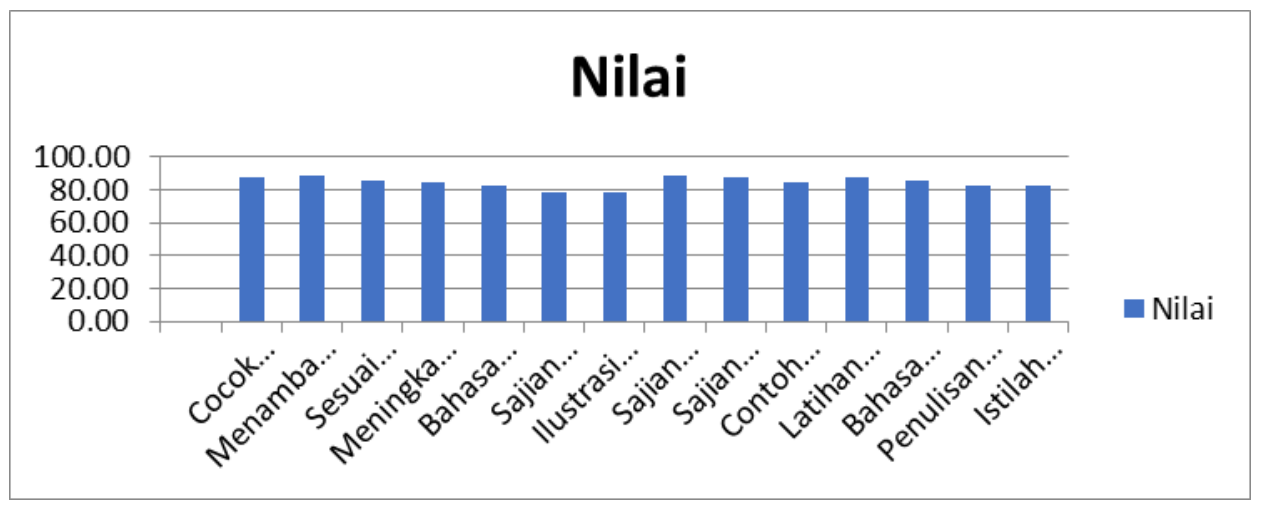

GAMBAR 1. Distribusi respon mahasiswa terhadap perangkat perkuliahan.

Berdasarkan diagram pada GAMBAR 1 terlihat bahwa duabelas dari empatbelas butir penilaian, direspon atau diapresiasi oleh mahasiswa dengan sangat baik, dan dua butir direspon dengan memberikan penilaian baik.

sebaran nilai mahasiswa untuk materi fungsi laboratorium, perangkat administrasi laboratorium, dan standar operasi laboratorium fisika sekolah menggunakan perangkat perkuliahan Manajemen Laboratorium, disajikan pada GAMBAR 2. 


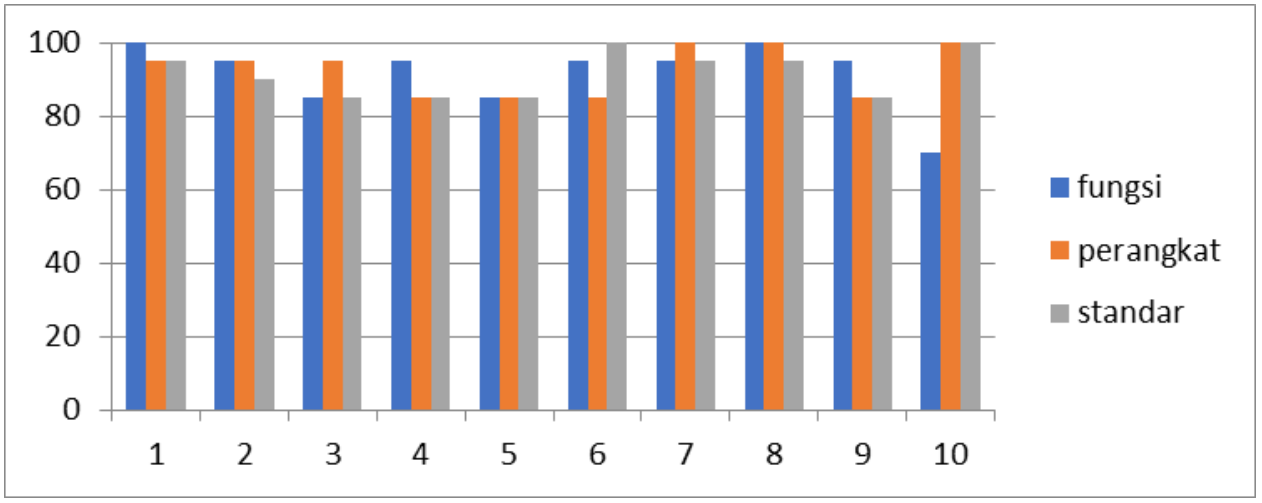

GAMBAR 2. Kinerja mahasiswa untuk tiga unit materi perkuliahan.

Garfik pada gambar dua memperlihatkan bahwa untuk materi fungsi laboratorium kisaran nilai mahasiswa dari 70 sampai 100, perangkat administrasi laboratorium antara 85 sampai 100, dan untuk materi standar operasi laboratorium fisika sekolah berkisar antara 85 sampai dengan 100.

Distribusi frekuensi nilai kinerja mahasiswa mengelola laboratorium fisika sekolah, disajikan pada GAMBAR 3.

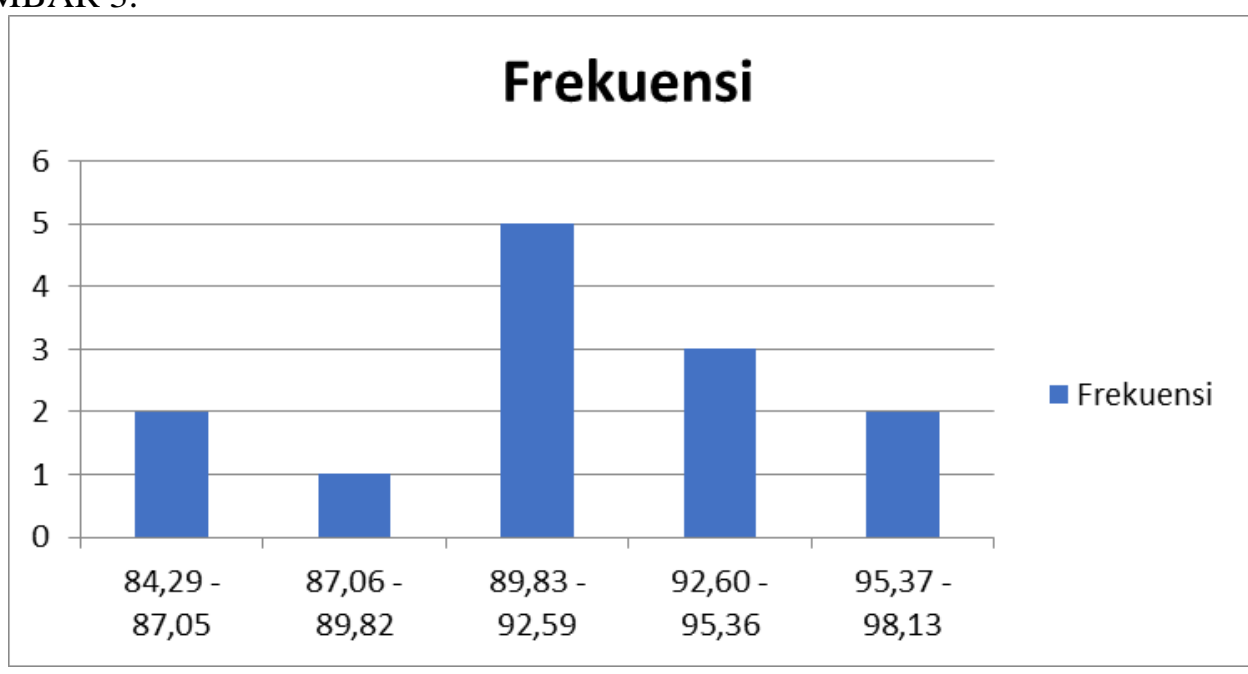

GAMBAR 3. Distribusi frekuensi nilai mahasiswa Mengelola Laboratorium.

Terlihat dari distribusi frekuensi nilai mahasiswa, bahwa kinerja mahasiswa mengembangkan bahan ajar fisika berdistribusi normal. Berkisar dari rentangan baik dan sangat baik. Puncak grafik berada pada kisaran 80,93 - 90,42, dengan kategori penilaian sangat baik. Hasil ini sejalan dengan hasil penilaian mahasiswaa terhadap perangkat perkuliahan.

\section{Pembahasan}

Data kualitatif yang dikumpulkan dengan cara wawancara atau lebih tepatnya disksusi intensi tentang produk penelitian yang dikembangkan, yang dilakukan dengan seluruh dosen pengampu mata kuliah kelompok dasar pendidikan fisika FMIPA UNJ, telah memberikan hasil yang sangat bemanfaat bagi dosen dan lebih bermanfaat lagi bagi mahasiswa. Silabus mata kuliah merupakan petunjuk pelaksanaan dan petunjuk praktis perkuliahan. Karena silabus dihasilkan dari beberapa kali diskusi intensi dengan sjumlah dosen, maka hasilnya menjadi sangat baik. Bahan ajar lain yang ditulis mengacu pada silabus, tentu menjadi terarah dan focus pada permasalahannya.

Respon positif yang diberikan mahasiswa terhadap perangkat perkuliahan berupa handout, Lembar Kegiatan Mahasiswa, dan Lembar Penilaian Kinerja Mahasiswa, menunjukan bahwa mereka tertarik dengan produk penelitian ini. Mereka perduli karena merasakan manfaatnya dalam perkuliahan Manajemen Labratorium. Seperti disampaikan pada hasil penelitian secara umum baik aspek isi, sajian, maupun bahasa diberi apresiasi sangat baik oleh mahasiswa. Dan hanya dua dari 
empat belas data data yang diapresiasi baik (78) oleh mahasiswa. Ini menunjukan bahwa perangkat perkuliahan ini sangat sesuai dengan kebutuhan mereka. Sehingga mereka puas dengan keberadaan perangkat perkuliahan tersebut.

Kondisi ini sangat masuk akal terjadi, karena proses pengembangan produk yang menerapkan langkah peneelitian ilmiah, dengan pengkajian mendalam terhadap kebutuhan mahasiswa pendidikan fisika di abad 21 ini. Dimana pembuatan produk ini dimulai dengan meminta masukan dari tim dosen kelompok mata kuliah Dasar Kependidikan Program Studi Pendidikan Fisika FMIPA UNJ. Telah dilakukan beberapa kali diskusi oleh tim MKDK pendidikan fisika. Diskusi dimulai dengan mengkaji KKNI Pendidikan fisika yang direkomendasikan oleh Asosiasi Program Studi Pendidikan Fisika Indonesia. Dimana KKNI tersebut disusun berdasarkan ketrampilan mengajar abad 21 dengan pendekatan ketrampilan proses sains.

Informasi yang berhasil kami serap kami jadikan sebagai masukan atau rujukan dalam mengembangkan semuaproduk penelitian ini. Sehingga cakupan materi, strategi, tagihan/ penugasan, dan produk mata kuliah sudah mendapatkan masukan dan mempertimbangan keterpenuhan kompetensi dan menghindari overlapping antar mata kuliah dalam kelompok MKDK.

Bahwa keberadaan perangkat perkuliahan hasil pengembangan ini sangat bermanfaat bagi mahasisa pendidikan fisika, tidak hanya tergambar dari respon atau apresiasi mahasiswa terhadap produk penelitian ini berupa perangkat perkuliahan manajemen laboratorium. Kondisi yang sejalan juga terlihat pada kinerja mahasiswa pada mata kuliah Manajemen Laboratorium. Nilai mahasiswa paling rendah 70 pada saat mereka menggunakan hand out, Lembar Kegiatan Mahasiswa, dan Lembar Penilaian Kinerja Mahasiswa hasil pengembangan. Ini berarti tidak ada mahasiswa yang memiliki predikat hasil belajar cukup apalagi kurang.

Nilai kinerja mahasiswa yang nominasi sangat baik, menunjukan bahwa mereka menguasai kompetensi pengelolaan laboratorium dengan sangat baik. Mahasiswa menilai perangkat perkulihan manajemen laboratorium sangat baik, karena mereka telah menggunakannya sebagai bahan ajar dalam mata kuliah tersebut, dan merasakan bagaimana bahan ajar tersebut memandu mereka untuk belajar, bekerja, dan menilai hasil kerja mereka.

Apabila mahasiswa belum benar-benar menggunakan perangkat perkuliahan ini, lalu memberikan penilaian berupa respon yang sangat baik, maka hasil belajar mereka tidak akan sejalan dengan respon yang mereka berikan. Tim peneliti meyakini bahwa data ini tidak direkayasa oleh mahasiswa, karena pada saat menyerahkan perangkat perkuliahan kepadaa mahasiswa kami mengingatkan kepada mahasiswa, bahwa kami menghrapkan masukan yang objektif, supaya dihasilkan perangkat perkuliahan yang benar-benar sesuai dengan kebutuhan, sehingga bermanfaat bagi mahasiswa.

Triangulasi data yang telah kami lakukan berupa kajian mendalam tentang kebutuhan mahasiswa yang informasinya didapat dari mahasiswa dan dosen yang terlibat sebagai pengampu mata kuliah kelompok dasar kependidikan, data tentang KKNI dari asosiasi Pendidikan Fisika se Indonesia, catatan diskusi intensif tentang kebutuhsn belajar mahasiswa pendidikan fisika abad 21, respon mahasiswa terhadap perangkat perkuliahan hasil pengembangan, serta nilai kinerja mahasiswa dalam mata kuliah Manajemen Laboratorium Fisika Sekolah, telah memberikan informasi yang saling mendukung.

Bahwa kajian yang mendalam terhadap kebutuhan mahsiswa telah menghasilkan silabus mata kuliah Manajemen Laboratorium yang konprehensif. Selanjutnya pengembangan perangkat perkuliahan yang mengacu pada silabus dan sumber belajar lainya, meghasilkan hand out, Lembar Kegiatan Mahasiswa, dan Lembar Penilaian Kinerja Mahasiswa yang teapat dan berhasilguns. Ketepataan dan keberhasilan ini adalah seperti telah terungkap dari respon mahasiswa yang sengat baik terhadap semua produk penelitian ini, yang diperkuat dengan nilai kinerja mahasiswa yang mencapai rerata sangat baik. 


\section{SIMPULAN}

Mengacu pada hasil dan pembahasan yang telah disampaikan, dapat disimpulkan bahwa: (1) Perangkat perkuliahan terpadu hasil pengembangan dapat meningkatkan kompetensi mahasiswa Pendidikan fisika terkait manajemen laboratorium fisika sekolah; (2) Silabus, Handout, Lembar Kegiatan Mahasiswa, dan Lembar Penilaian Kinerja Mahasiswa berbasis ketrampilan proses sains, yang hasil pengembangan, layak digunakan sebagai bahan ajar untuk mata Manajemen Laboratorium Fisika Sekolah.

\section{REFERENSI}

Hamid, Ahmad Abu. 2011. Sistem Manajemen Laboratorium MIPA. Yogyakarta: Makalah Pengabdian Kepada Masyarakat (PPM) UNY.

Nugroho, U. 2009. Penerapan Pembelajaran Kooperatif Tipe STAD Berorientasi Keterampilan Proses. Semarang: Jurnal Pendidikan Fisika Indonesia 5.

Romlah, Oom. 2009. Peranan Praktikum dalam Mengembangkan Keterampilan Proses dan Kerja Laboratorium. Garut: MGMP Biologi Kabupaten Garut.

Syahbana, Ali. 2012. Pengembangan Perangkat Pembelajaran Berbasis Kontekstual untuk Mengukur Kemampuan Berpikir Kritis Matematis Siswa SMP. Bengkulu: Edumatica Vol. 02 No. 02.

Wardani, Sri. 2008. Pengembangan Keterampilan Proses Sains dalam Pembelajaran Kromatografi Lapis Tipis melalui Praktikum Skala Mikro. Semarang: Jurnal Inovasi Pendidikan Kimia.

Werdayanti, Andaru. 2008. Pengaruh Kompetensi Guru dalam Proses Belajar Mengajar di Kelas dan Fasilitas Guru Terhadap Motivasi Belajar Siswa. Semarang: Jurnal Pendidikan Ekonomi Vol 3 No.1. 
